Notre Dame Law School

NDLScholarship

Journal Articles

Publications

2006

\title{
The Federal Constitutional Court: Guardian of German Democracy
}

Donald P. Kommers

Notre Dame Law School, donald.p.kommers.1@nd.edu

Follow this and additional works at: https://scholarship.law.nd.edu/law_faculty_scholarship

Part of the Comparative and Foreign Law Commons, Constitutional Law Commons, Courts Commons, and the Law and Politics Commons

\section{Recommended Citation}

Donald P. Kommers, The Federal Constitutional Court: Guardian of German Democracy, 603 Annals of Am. Acad. of Pol. \& Soc. Sci. 111 (2006).

Available at: https://scholarship.law.nd.edu/law_faculty_scholarship/1377

This Article is brought to you for free and open access by the Publications at NDLScholarship. It has been accepted for inclusion in Journal Articles by an authorized administrator of NDLScholarship. For more information, please contact lawdr@nd.edu. 


\section{The Federal Constitutional Court: Guardian of German Democracy}

\author{
By \\ DONALD P. KOMMERS
}

Germany's Federal Constitutional Court rivals the Supreme Court of the United States in protecting political democracy. Its jurisprudence of democracy has shaped the course and character of German politics while upholding the rule of law and defending the constitutionally prescribed "free democratic basic order." In furtherance of these objectives, the Constitutional Court has invalidated regulations limiting the rights of minor parties and constitutionalizing measures designed to stabilize Germany's system of parliamentary government. These purposes have been served by constitutional decisions on voting rights, public funding of election campaigns, dissolution of Parliament, and proportional representation, including the limiting 5 percent clause. These decisions, along with a discussion of the Hessian Election Review Case - a reminder of Bush v. Gore - are calculated to make political representation both responsive and responsible and to anchor the political system firmly in the democratic values at the heart of the Basic Law.

Keywords: Germany; party finance; democracy; representation; voting rights; parliament

$\mathrm{T}$ his article focuses on the constitutionalism of democracy in Germany. The Basic Law, Germany's constitution, defines the nature of this democracy in abundant detail. It provides for its organization and procedures and imposes substantive limits on its exercise. The constitution also empowers Germany's Federal Constitutional Court (FCC) to monitor the process of democracy and to keep it tethered to constitutional values. Over the course of the past fifty years, the court has produced a significant body of constitutional case law on the meaning and

Donald P. Kommers is the Joseph and Elizabeth Robbie Professor of Political Science and concurrent professor of law at the University of Notre Dame. He has written widely on American and comparative constitutional law and is the author of The Constitutional Jurisprudence of the Federal Republic of Germany (2nd ed. 1997), among other books, and coauthor of American Constitutional Law: Essays, Cases, and Comparative Notes (2004). His numerous awards and fellowships include an honorary doctor oflaws degree he recently received from Germany's Heidelberg University.

DOI: $10.1177 / 0002716205283080$ 
limits of democracy. In doing so, the FCC has played a major role in shaping the character and course of German politics. Its decisions, and the willingness of Germany's political class to abide by its rulings, are partly responsible for transforming what was once an underdeveloped political culture into one of the world's most advanced and influential parliamentary democracies, one unmistakably governed by the rule of law.

Some preliminary remarks about the Basic Law and judicial review in Germany will place the FCC's decisional law on democracy in a more helpful context. Accordingly, this article begins with a glance at Germany's constitutionally prescribed structure of democracy and popular sovereignty. It continues with a brief discussion of the FCC's jurisdiction and its role in the nation's constitutional order and then considers selected constitutional cases on democracy likely to interest American readers. This short treatment is more descriptive than analytical. It is mainly an overview of the FCC's most important decisions on election law, political parties, and parliamentary democracy. Along the way, and where relevant, it may be useful to draw attention to the equivalent jurisprudence of the United States Supreme Court.

\section{Democracy and the Basic Law}

The Basic Law of the Federal Republic of Germany, adopted in 1949 in the aftermath of Germany's defeat in the Second World War, has evolved into one of the world's most influential constitutions. This is certainly the case if influence can be measured by the frequency with which the Basic Law's provisions - and institutions - have been copied or adopted by constitution makers around the globe (Kokott 1999). Most influential among these provisions are those dealing with Germany's parliamentary system of government, particularly the Basic Law's decrees on political parties and its internal order of democracy, together with its creation of a constitutional court authorized to review and decide controversies arising under these provisions. The following summary is confined mainly to those clauses and paragraphs prominently featured in the constitutional cases discussed later in this article.

Let us begin with Article 20, paragraph 1, of the Basic Law, which defines the Federal Republic of Germany as a "democratic and social federal state" (emphasis added). Paragraph 2 reinforces this concept by declaring that "all state authority emanates from the people." The next sentence, however, emphasizes the representative character of the governing process, for the authority emanating from the people "shall be exercised by ... means of elections and voting and by specific legislative, executive, and judicial organs," a system of representation, as the FCC has frequently observed, that disallows all popular initiatives, plebiscites, or referenda at the national level. ${ }^{1}$ In addition, Article 38, paragraph 1, provides that members of Parliament (the Bundestag) "shall be elected in general, direct, free, equal, and secret elections" and then stipulates that they "shall be representatives of the whole people, not bound by orders or instructions, and responsible only to their 
conscience." Yet the Basic Law establishes political parties as major agencies of political representation. Their function, according to Article 21, paragraph 1, is to "participate in the formation of the political will of the people," for which reason the FCC has characterized Germany as a "party state" (Parteienstaat), one in which political parties enjoy constitutional status, allowing them to adjudicate their rights as primary agents of electoral politics (1 BVerfGE 208, 225: 1952). ${ }^{2}$

\section{[T] he FCC [Federal Constitutional Court] \\ has evolved into one of Germany's most important policy-making institutions, a remarkable development in view of the nation's long tradition of executive predominance in constitutional matters.}

As for electoral politics, it is important to note that members of the Bundestag are elected for four years, a constitutional mandate that imposes severe limits on the power to vote a chancellor out of office or to dissolve Parliament before the expiration of the normal four-year election cycle. Under the so-called "constructive vote of no confidence," set forth in Article 67, the Bundestag may remove a chancellor in a no confidence vote only by electing his successor simultaneously by a majority of its members. A new federal election is permitted ahead of schedule, however, only when the chancellor himself initiates procedures specified by Article 68 . First, he must formally move for a vote of confidence in the Bundestag; second, the Bundestag by a majority of its members must vote against him; third, the chancellor must then petition the federal president to dissolve the Bundestag; fourth, the president must agree to do so and arrange for new elections to be held within sixty days. Finally, as noted later in the article, each of these procedures is subject to review in the FCC.

The electoral system as such, which the Basic Law empowers Parliament to determine, is another distinctive feature of German democracy. From the outsetsince 1949-the system, often called "personalized" or "modified" proportional representation (PR) (Sartori 1997), has combined single-member districts with PR. Federal law now provides for 598 members of the Bundestag, one half of whom are elected in single-member districts in which a plurality of votes is sufficient to win; the other half is elected by PR. Accordingly, voters receive two ballots. On the first, they record their choice of a district representative; on the second, 
they vote for a closed list of party candidates. The outcome of the list ballot determines the total number of parliamentary seats allocated to each party. If, for example, party A wins 38 percent of the national vote, it receives that percentage of parliamentary seats. If the total number of district representatives equals less than 38 percent of party A's parliamentary membership, the remaining representatives are drawn from the list ballots until the prescribed percentage is reached. But if party A wins no district seats, all of its members are drawn from party lists.

This system, however, is skewed in two ways. First, if a major party wins more district seats than it would be entitled to under strict PR, it keeps these surplus or "overhang" seats (Überhangsmandate), as they are called. Second, under the law's famous "barrier clause" (Sperrklausel), a party receiving less than 5 percent of the national vote is excluded altogether from parliamentary representation unless it wins at least three district seats, in which case it is entitled to representation proportionate to its total national vote even though that vote is less than 5 percent. The idea behind this electoral arrangement is that a party capable of winning three district seats—a difficult achievement-has sufficient popular support to warrant full representation under PR. But if the party wins one or two district seats - and no more-and falls below the 5 percent requirement, it retains only these seats with no additional ones under PR.

The Basic Law, finally, contains numerous references to the "free democratic basic order" whose defense-like that of the principle of human dignity set forth in Article 1 - the state is duty-bound to protect. As deployed in the Basic Law, these terms limit the boundaries of freedom for they do not protect the enemies of democracy. For example, guaranteed rights such as freedom of expression or the right to associate can be forfeited if used to combat democracy (Article 18). Most important for present purposes is Article 21, paragraph 2, which declares "unconstitutional" those political parties seeking to undermine or abolish the free democratic basic order. As with the forfeiture of basic rights, only the FCC may rule on the question of a party's constitutionality. Early on, in the famous Communist Party Case, the FCC seized upon these and related provisions to describe the German polity as a "militant democracy" (5 BVerfGE 85, 139: 1956).

\section{The Federal Constitutional Court}

The Basic Law re-created many of the political structures established by the Weimar Constitution of 1919 but eliminated those crippling defects that weakened Weimar's democracy and facilitated Hitler's rise to power. Several of the Basic Law's innovations have helped to stabilize Germany's political system. These include the elevated status of the chancellor as the nation's political leader, the correspondingly diminished power of the president, the constructive vote of no confidence, the 5 percent Sperrklausel, and the difficulty of dissolving Parliament and holding new elections ahead of schedule (Conradt 2001). Each has contributed to the durability of Germany's postwar democracy. But the most striking innovation 
of all was the creation of a constitutional court empowered to enforce guaranteed rights and to decide other controversies arising under the Basic Law. ${ }^{3}$

Established in 1951 after months of parliamentary negotiations (Kommers 1976; Schlaich and Korioth 2001), the FCC has evolved into one of Germany's most important policy-making institutions, a remarkable development in view of the nation's long tradition of executive predominance in constitutional matters. Organizationally, the FCC consists of two senates, each staffed by eight justices elected by the legislative branch of the national government for nonrenewable terms of twelve years. ${ }^{4}$ The two senates exercise mutually exclusive jurisdiction that, taken together, extends to virtually all issues concerning the German nationfrom abortion policy to military and international affairs — even to pedestrian disputes over the validity of rules pertaining to the correct usage of the German language (98 BVerfGE 218: 1998). As a specialized court of constitutional review, the FCC is the only tribunal in Germany empowered to declare statutes and other governmental actions unconstitutional.

The Basic Law lists sixteen categories of constitutional disputes over which the FCC has jurisdiction. The most important of these for present purposes are federal-state and separation of powers conflicts, abstract and concrete judicial review proceedings, and constitutional complaints. Apart from constitutional complaints, only governments and specified public officials have standing to petition the FCC to resolve constitutional disputes. These "officials" include candidates for public office and individual members of Parliament seeking to vindicate their electoral or representational rights. Political parties may also petition the FCC in defense of their corporate rights in and out of Parliament. Ordinary citizens may file constitutional complaints but only after they have exhausted all other legal remedies. Characteristically, in ordinary litigation before the regular courts, the conflicting parties have no standing to raise constitutional issues. In regular or concrete judicial review proceedings, only judges may place questions before the FCC and then only if they seriously doubt the constitutionality of the law or laws they are called upon to enforce or interpret. But the FCC is not limited to reviewing "cases and controversies" in the American understanding of these terms. At the request of the federal or a state government or one-third of the Bundestag's members, the FCC may resolve-in an abstract judicial review proceeding - mere doubts about the constitutionality of an enacted law or the compatibility between federal and state law. A major function of the FCC, as the guardian of the Basic Law, is precisely to resolve such doubts when raised by major political officials or state actors in managing the course of the nation's public life. For the German public mind, this is what it means to be governed by law, in this instance by the law of the constitution.

A glimpse at the court's workload is enough to give us a sense of the importance of judicial review in German life and law. In its fifty-three years, down to 2005, the FCC has decided some 150,000 cases, 144,000 of which have been constitutional complaints filed by individual citizens (Bundesverfassungsgericht 2004). The main body of its jurisprudence is to be found in 113 volumes (to date) of official reports consisting of some 2,700 full opinions. This vast body of constitutional law is fully comparable, in significance and sophistication, to the decisional law of the U.S. 
Supreme Court, except that numerous disputes decided by the Constitutional Court would be regarded as nonjusticiable in American courts. As underscored by the frequency with which the FCC decides cases involving foreign and military affairs, there is no equivalent in Germany to the American political question doctrine, although in many such cases the court applies a presumption of constitutionality (Franck 1992).

\section{The Jurisprudence of Parliamentary Democracy}

The law of democracy in Germany represents a vast jurisprudence. A trip through this body of law would show that the FCC has decided controversies touching almost every phase of electoral and parliamentary politics, including the role, status, and funding of political parties. Nearly all these decisions pertain to the quantity, quality, or equality of political representation (Jesse 1985; Currie 1994, 104-16). In a series of cases over the years, the FCC has handed down decisions ordering higher salaries for legislative representatives (40 BVerfGE 296: 1975); invalidating laws unduly restricting political parties from gaining access to the ballot (3 BVerfGE 19: 1953; 5 BVerfGE 77: 1956; 12 BVerfGE 10: 1960); forbidding political parties from changing the order in which candidates appear on party list ballots (7 BVerfGE 77: 1957); limiting the conditions under which a minor parliamentary party can be excluded from representation on a legislative committee (70 BVerfGE 324: 1986; 80 BVerfGE 188: 1989); barring Parliament from excluding a representative from a legislative committee merely because he or she is not a member of a political party (84 BVerfGE 304: 1991); and vindicating the rights of parliamentary minorities to establish investigative committees to hear evidence of illegal or improper conduct by a ruling governmental majority, largely on the theory that in modern parliamentary democracies separation of powers manifests itself most effectively not in the checks and balances among branches of government but in the duty of opposition parties to confront and publicize the misdeeds of the ruling majority (49 BVerfGE 70: 1978).

The remaining cases discussed in this article focus on constitutional policies characteristic of Germany's parliamentary system. They are important because they implicate efforts to stabilize party government, to make political representation responsive and responsible, and to anchor the system more generally in the democratic values at the heart of the Basic Law. The following pages cover five sets of constitutional cases that are likely to fascinate readers not only for their intrinsic merit but also for their contrast with American constitutional perspectives and procedures. The first category deals with PR and the 5 percent clause (Sperrklausel); the second focuses on voting rights and their relationship to Germany's PR system; the third describes constitutional policies related to the public funding of political parties; the fourth shifts attention to a recent election case vaguely reminiscent of Bush v. Gore (531 U.S. 98 [2000]; and the fifth highlights the limits the Basic Law places on the power to dissolve Parliament. 


\section{PR and the Sperrklausel}

As noted, Germany's electoral system combines PR with single-member districts (Kitzinger 1960). German law, however, qualifies PR by requiring a party to garner at least 5 percent of the vote to enter the national Parliament. This personalized PR system prevails in thirteen of Germany’s sixteen Länder. A simple PR system prevails in Bremen, Hamburg, and Saarland, but these states have also adopted

\section{In numerous decisions over the years ... the FCC has imposed severe limits on the scope and allocation of public funding, virtually micromanaging the field of party finance.}

the 5 percent clause (Gunlicks 2003). Like the U.S. Supreme Court, the FCC has ruled that single-member legislative districts are to be approximately equal in population (16 BVerfGE 130: 1963), but the addition of PR in its view makes the electoral system as a whole both equal and fair. Finally, in the interest of effective governance, the FCC has approved the use of the 5 percent clause (6 BVerfGE 84: 1957), although in one of its earliest decisions it ruled that only a compelling reason would justify a threshold requirement beyond what it called the "common German value of five percent" (1 BVerfGE 208: 1952).

In 1990, however, the court struck down the application of the 5 percent rule to the first all-German election following reunification (82 BVerfGE 322: 1990). Calculated to advance a constitutionalism of reconciliation and inclusion, this unanimous decision illustrates the protection the FCC customarily affords to minor parties. In short, the court sought to ensure that certain political parties in the eastern states, notably the previously dominant Communist Party — now called the Party of Democratic Socialism (PDS) — would have a fighting chance to enter the new, allGerman Parliament. ${ }^{5}$ The FCC reiterated its view that the 5 percent threshold is "constitutionally unobjectionable" as a general principle, but special circumstances may dictate a modification of the rule if the "political will of the electorate" is to be realized. Accordingly, and on the FCC's recommendation, the Bundestag provided that the 5 percent clause should apply separately in east and west, thus enabling the eastern Green Party and PDS to win parliamentary representation. The rule would apply only to the 1990 election, giving the eastern parties a chance to establish themselves nationally. The FCC made clear that Germany could revert to its established electoral system in subsequent federal elections. 
In recent years, minor parties have mounted additional challenges to the 5 percent rule. They have also questioned the constitutionality of overhang seats, alleging that they violate the principle of proportional representation. The practice of awarding surplus seats to the major parties met its severest test in the Overhang Mandate Case (95 BVerfGE 335: 1997), an abstract judicial review petition filed by Lower-Saxony. In a four-to-four decision, the FCC's Second Senate upheld the validity of surplus mandates because the electoral system as a whole fostered a personal relationship between voters and their elected representatives. (It takes a majority of the justices to nullify a law.) The dissenting justices argued that surplus seats violated the principle of equality under PR, requiring a change in federal law. In a related case, decided on the same day, the FCC sustained a decision of the Bundestag to award the PDS the four district seats it had won in East Berlin, along with the twenty-six seats it was entitled to under PR, a number equal to 4.4 percent of the national vote it received in 1994. By vindicating the rule that such a party should be entitled to proportional representation even though it fails to meet the standard 5 percent requirement, the FCC felt that it was promoting equality among the parties (95 BVerfGE 408: 1997).

\section{Voting rights and democracy}

As noted in the previous section, the FCC has not only enforced the principle of direct, free, and equal suffrage, but also that of fair and effective representation. The court has emphasized the importance of the personalized nature of the electoral system, meaning that when citizens vote they cast their ballots for particular candidates running in single-member districts and for the order in which candidates appear on party lists (Kommers 1997, 181-97). A distinguishing feature of these decisions is the direct link the FCC has sought to establish between the people, voting, and public policy. As Article 20, paragraph 2, of the Basic Law declares, "All state authority is derived from the people" and exercised by them "through elections" and through "specific legislative ... bodies." The FCC has made clear that the "people" in this instance refers to Germans and that any attempt to break the link in the chain between the will of Germans and their representatives offends the principle of democracy as laid down in the Basic Law.

The principle of democracy was implicated most notably in the celebrated Maastricht Treaty Case (89 BVerfGE 155: 1993). Maastricht was a surprise procedurally because the FCC accepted it as justiciable in the form of individual constitutional complaints under the right-to-vote provisions of Article 38. In their complaints, voters alleged that by transferring certain legislative powers to the European Union without the consent of Parliament, the government would invade their rights as voters and undermine the principles of both democracy and popular sovereignty. Although the FCC found the treaty compatible with the Basic Law, it warned the government that the $\mathrm{EU}$ threatened to break the chain of legitimation between voters and their representatives. In a highly controversial opinion, and a unanimous one at that, the FCC suggested that the transfer of authority to the EU in the face of its "democratic deficit" would diminish the voting rights of the peo- 
ple — the German people — and the authority of the elected parliament responsible to them for the powers it exercises. The court's decision produced shockwaves throughout Germany and Europe. Despite holding that the national Parliament retained sufficient control over its powers to satisfy the principle of democracy, the court faulted the EU for its lack of democratic representation, suggesting along the way that the legitimacy of EU policy will depend on maintaining the link between German voters, their national parliament, and the European Parliament (Pernice 1993; Kokott 1994; Meeson 1994; Foster 1994). ${ }^{6}$

Three years before Maastricht, the court had ruled that the concept of "the people" for the purpose of voting included only German citizens and not foreign residents working in Germany. Schleswig-Holstein and Hamburg had permitted foreign residents to vote in local elections. The FCC nullified the laws of both Länder. Voters, the court said, must be citizens unified by their common membership in and allegiance to the "body politic" (83 BVerfGE 37: 1990; 83 BVerfGE 60: 1990). Two years later, however, the Maastricht Treaty extended the franchise to all European citizens residing in a member state. It was clear that a constitutional amendment would be necessary to validate the treaty provision. Accordingly, in December 1992, the Basic Law was amended to grant the nationals of member states the right to vote in local Land elections (Article 28 [1]), effectively nullifying the FCC's foreign voting decisions.

In the Official Propaganda Case, finally, the FCC refined its conception of representative democracy. During the 1976 federal election campaign, the Social Democratic-controlled government had distributed millions of informational leaflets and brochures, including the text of various laws and treaties, describing the records of and benefits conferred by federal ministries. The Christian Democratic Union (CDU) petitioned the FCC to ban this practice. In response, the court ruled that the practice violated not only the principle of parliamentary democracy under Article 20, but also the equality of political parties under Article 21 and the principle of free and equal elections under Article 38. State agencies, said the court, may not take sides during an election campaign. The Basic Law provides "for a free and open process of forming the popular will" just as voters and parties must be left free "to form and utter their opinions fully and openly." Similarly, noted the court, political parties must begin their election campaigns at the same starting line if there is to be a free and equal process of forming, in the words of the Basic Law, "the political will of the people." Political scientists might well question a theory of democracy that posits, empirically, a direct relationship between voting and the people's will, but it is one to which the FCC has faithfully adhered.

\section{Public funding of political parties}

A distinctive feature of German constitutionalism is the formal recognition of political parties as "quasi-constitutional organs." In fact, as noted earlier in this article, Germany is officially known as a "party state" (Leibholz 1973, 68-94), one described by Michaela Richter $(1995,37)$ as "a unique synthesis of Western parliamentarism and the German state tradition." The parliamentary tradition finds its 
embodiment in the principle of popular sovereignty and the formal institutions of democracy. The state tradition, on the other hand, is manifest in the Basic Law's formal recognition of political parties as agencies engaged in the process of "will formation" and in their status - one the FCC has conferred by interpretationas "integral units of the constitutional state" (1 BVerfGE 208, 225: 1952). Already in 1954, the FCC ruled that in their capacity as constitutional organs of the state, political parties may defend their institutional rights before the court in an Organstreit (interbranch conflict) proceeding (4 BVerfGE 27: 1954), empowering parties to challenge an infringement of their electoral rights much as a branch of government would seek to vindicate its rights under the principle of separation of powers.

Like the U.S. Supreme Court, the Constitutional Court has played a major role in the field of party finance, but with results emphasizing equality of party competition over arguments rooted in free speech rights, as in the United States. In an early case, the court invalidated tax provisions allowing individuals and corporations to deduct their contributions to political parties for discriminating against those parties - the Social Democratic Party (SPD) in particular-disfavored by wealthy persons and the German business community. (A year earlier, the court had nullified a law disallowing tax deductions for contributions to political parties unless the latter elected at least one representative to the national or a state parliament [6 BverfGE 273: 1957].) In this case, the court took the unusual step of recommending, in the interest of fair and equal elections, the public financing of election campaigns. Parliament obliged, its enthusiasm for state financing fully matching the generosity of its appropriations. By the late 1980s, total party income had reached DM 608.5 million, 36 percent of which consisted of public subsidies; by 1994, public subsidies accounted for 40 percent (DM 352 million) of the total party income of the parties (Nassmacher 2001, 96).

In numerous decisions over the years, however, the FCC has imposed severe limits on the scope and allocation of public funding, virtually micromanaging the field of party finance. An inaugural party finance law was invalidated by the court because it covered party activities well beyond campaign expenditures (20 BVerfGE 56: 1966). This decision sought to reconcile the tension between Articles 21 and 38. Under the first, parties are charged with competing for an electoral mandate, but under the second, representatives are declared to be independent and not bound by instructions. To allow financing unrelated to elections, said the court, would give political parties a monopoly over the formation of public opinion. Between elections, parties are fully entitled to raise money on their own, but they do so as private entities. They assume the character of constitutional organs only in their capacity as electoral organizations. Accordingly, public funding must be limited, constitutionally, to legitimate campaign expenses.

In subsequent decisions, the court has monitored laws relating to the disclosure of party contributions, tax-deductible donations to the parties, and the formulae for allocating public funds among the parties, imposing standards and limits on each of these measures, all in the interest of establishing a level playing field for political parties competing for a proportionate share of the national vote 
(Kommers 1997, 200-215). In one decision, the FCC lowered the publicity threshold for contributions from the legislatively established figure of DM 40,000 to DM 20,000. As for public subsidies, the FCC disallowed legislation denying public funding even to independent candidates and, in the same opinion, struck the denial of funds to parties unrepresented in Parliament as well as to those receiving

\section{[W] hile the court has limited the right of foreign residents to vote in local and municipal elections, it has otherwise sought to root Parliament's law-making powers in elections and the exercise of the franchise.}

less than 2.5 percent of the popular vote (41 BVerfGE 399: 1976). In fact, the court proceeded to order Parliament to lower the 2.5 figure to 0.5 percent, a rule seemingly undercutting the logic behind the FCC's approval of the 5 percent clause. By 1992 , however, the court concluded that it was no longer reasonable or practicable to distinguish between campaign costs and other political party expenditures (85 BVerfGE 164: 1992). From now on, ruled the court, state funding could not exceed the total amount raised by the parties themselves and, in a parting shot, admonished the Bundestag to change the law accordingly by January 1993 (Gunlicks 1994).

\section{Hessian Election Review Case}

The Hessian Election Review Case (103 BVerfGE 111: 2001) arose out of a party finance scandal in Hesse, one of Germany's most populous states. It warrants attention not only for the issues it raises but also for the affinity it bears to Bush v. Gore (531 U.S. 98 [2000]), the controversial case that decided the American presidential election of 2000 (Gillman 2001). Bush was controversial because many legal scholars, including four dissenting justices on the Supreme Court, thought the case failed to present a substantial federal question and should have been decided at the state level. Others advanced the view that Bush presented a "political question" unfit for judicial resolution (Chemerinsky 2001). Hessian Election, on the other hand, like most cases coming before the FCC, stands for the proposition that any case arising under the Basic Law and properly before the court is fully justiciable. Bush presents precisely the kind of issue-were such a case to arise in 
Germany - that the FCC would feel obliged to resolve. The idea that certain constitutional issues, although legitimately before the FCC, should be dismissed because of their political character would offend the German sense of constitutional justice and the rule of law.

The facts of Hessian Election, though complex, can be summarized briefly. Christian Democrats, having narrowly won the 1999 Hessian state election, formed a coalition government with Liberal Democrats, thus relegating Social Democrats and the Alliance 90-Greens to the role of opposition, a rarity in this largely SPD state. It was discovered later, however, that the CDU campaign had been financed by illegal campaign funds stashed away in a Swiss bank account, whereupon, relying on state law, Social Democrats sought to nullify the election. State law provided for an Election Review Court (Wahlprüfungsgericht) composed of both judges and legislators. Its jurisdiction included the power to void an election resulting from a breach of "public morality," a decision state law defined as final. But when the review court opened its inquiry at the request of the SPD, the new coalition government immediately challenged the proceeding before the FCC in an abstract judicial review petition, arguing that the inquiry conflicted with the constitutional principles of popular democracy, the rule of law, and separation of powers (103 BVerfGE 111, 113-23: 2001). Three principal rulings emerged from the FCC's decision. First, the court found that the establishment of an election review court was fully authorized by Article 28 of the Basic Law, requiring all Land governments to conform to "the principle of a . . democratic . . . state governed by the rule of law." Second, the court sustained the validity of statutory provisions providing for the nullification of an election tainted by bad morals. But the court narrowly construed the meaning of "public morality," declaring that the offensive conduct must influence the election and significantly affect its outcome. "Declaring an election invalid," said the court, "requires electoral irregularities of such magnitude that keeping the elected people's representatives in office would appear intolerable" (author's translation). The FCC went on to hold that no such breach occurred in the Hessian election. Third, the FCC ruled that the Election Review Court contravened Article 92 of the Basic Law, which vests judicial power in "judges." Because the review court included legislators, said the FCC, it offended the principle of separated powers. Also declared unconstitutional was the inability to appeal the election court's decisions to a higher court. The rule of law, said the FCC, requires that its decisions be subject to appellate review. One month later, finally, Hesse's Election Review Court decided that the CDU's use of illegal funds, however regrettable, did not violate "public morality" as defined by the FCC, and thus could not be said to have unlawfully influenced the outcome of the state election (Miller 2004).

Without appearing to digress too far from the jurisprudence of democracy itself, one might point out important differences between certain German and American judicial practices. First, Hessian Election was a unanimous decision despite its partisan nature and the even split on the Second Sensate between justices nominated by the CDU and those nominated by the SPD. Bush v. Gore, by contrast, was a split decision, with the court's five "conservative" justices deciding in favor of Bush. 
Interestingly, German legal scholars known to the author have expressed surprise and even disdain for the frequency of five-to-four decisions on the Supreme Court-not to mention the multiplicity of concurring and dissenting opinions found in numerous other cases - a practice they have a hard time reconciling with clear rules of law. On the other hand, abstract judicial review is a practice that would find little support among American lawyers and judges. Confining federal judicial power to concrete "cases and controversies" is, of course, deeply embedded in the common law tradition and American legal culture (Ripple 1984). It is also the product of the Supreme Court's respect for the legitimate roles of Congress and the executive in the American system of government. In Germany, by contrast, abstract and concrete review cases are not designed to vindicate an individual's claim to a constitutional right or even that of the official party petitioning for review, but rather to vindicate the public's interest in constitutional government and the validity of law. At stake is the constitutional order itself as well as the integrity of the legal order as a whole (Kommers 1997, 42-48).

\section{Dissolving Parliament}

This article goes to press just as the FCC has sustained the decision of the federal president to dissolve Parliament and to hold a national election-on September 18, 2005-a full year in advance of the regularly scheduled election. The controversy surrounding this case might also remind Americans of Bush v. Gore, for the questions it presents are as much political as constitutional, and they touch the heart of Germany's parliamentary democracy. The controversy began with Chancellor Schröder's recent plan to dissolve the Bundestag and hold a new federal election ahead of time, a plan motivated by a string of local election defeats that left the Social Democratic-Green coalition in charge of only four of Germany's sixteen states (Länder), compared to the eleven it controlled in 1998. A fresh election, it was hoped, would produce a new governing mandate the chancellor desperately wanted and needed. The chancellor, however, was not only taking a calculated political risk; he was also betting on the strategy's constitutionality. As noted earlier, Parliament can be dissolved under Article 68 only when the chancellor initiates a vote of no confidence, loses, and then requests the president to dissolve the Bundestag in the hope that he will do so. These procedures should be distinguished from the constructive vote of no confidence permitted by Article 67, pursuant to which the Bundestag itself may remove a chancellor but only by simultaneously electing his successor by a majority of its members. If confidence is withheld and the Bundestag fails to elect a new leader, the chancellor remains in office at the head of a minority government.

Article 67, like Article 68, was a master stroke of constitutional engineering, for it has helped to stabilize Germany's political system. Since the Bundestag cannot dissolve itself, its members - that is, members of the governing parties — are ill disposed to turn themselves out of a ruling coalition unless they are confident of rejoining the government under a new chancellor. It is unsurprising, therefore, that the Bundestag has invoked Article 67 only twice in the Federal Republic's his- 
tory, first in 1972 when Willy Brandt barely held off a Christian Democratic challenge to his leadership and then again in 1982 when the Bundestag chose Helmut Kohl to replace Helmut Schmidt as chancellor following the Free Democratic Party's decision to withdraw from the latter's coalition and shift its support to Christian Democrats. Schröder's initiative under Article 68, however, is the third time in Germany's postwar history that a chancellor has resorted to its procedures. Both Brandt and Kohl sought early elections shortly after their just-mentioned victories in the Bundestag in 1972 and 1982, respectively. In these two situations, the strategy worked. The ensuing elections produced substantial parliamentary majorities for both chancellors.

Counting on, or hoping for, a similar result, Chancellor Schröder initiated his no confidence vote on July 1, 2005, and lost as planned, permitting him to petition the federal president for an order to dissolve the Bundestag. Had President Horst Köhler concluded that the chancellor had contrived to lose a vote of confidence, he might have disallowed the request on the ground that the chancellor actually commanded the support of a parliamentary majority. But on July 22 , President Köhler-formerly a member of the CDU (the opposition party)—accepted Schröder's argument that he could no longer govern effectively, remarking that "the well-being of the people is best served by new elections." Shortly thereafter, two members of the Bundestag, from the SPD and the Greens, respectively, filed an Organstreit proceeding challenging the validity of the president's action, ${ }^{7}$ arguing that the order of dissolution in the face of actual majority support for the government violated their electoral mandates, ones coextensive with the prescribed four-year terms for which they were elected in 2002.

The judicial petition was not unprecedented, for the FCC decided a similar complaint when members of the Bundestag contested the validity of new elections ordered by the federal president in 1983 at the request of Chancellor Kohl. A full month prior to the newly scheduled election, and over the reservations of several constitutional scholars, the FCC, in a six-to-three opinion, backed the president, asserting that the decision to dissolve Parliament was within his discretionary authority (62 BVerfGE 1: 1983). In the course of its opinion, the FCC distinguished between the "formal" and "material" conditions for dissolving Parliament under Article 68. The formal requirements, as already noted, are four, involving, respectively, the chancellor's call for a vote of confidence, the Bundestag's "no" vote, the chancellor's request to the president, and the president's acceptance of the request. The material condition added by the court requires a "situation of instability" (eine Lage der Instabilität) that would in fact undermine the ability of the ruling coalition to govern effectively.

Accordingly, the FCC made clear each of the decision makers along the waychancellor, Bundestag, and president-is duty-bound to consider the Basic Law's sharp limits on the power of dissolution. Each is required, independently and conscientiously, to decide whether the political divisions in the Bundestag had seriously impaired the ruling coalition's capacity to govern. Yet the FCC emphasized the political nature of each judgment, thus blurring the line between constitutional law and politics. Although the FCC stood ready to render its own judgment on the 
merits of any proposal for dissolution, the justices in the majority held that the president in particular should allow the chancellor a certain political leeway (Spielraum) in determining whether he is faced with a "situation of instability" that would justify new elections.

Initially, it was unclear whether Schröder's Article 68 gambit would succeed in the light of the FCC's 1983 decision. Yet the chancellor's reasoning seemed as compelling as Kohl's in 1983. First, Schröder had a scant 13-vote majority in the Bundestag (out of 603 members); second, he seemed reasonably convinced that opposition on certain issues from the Greens - the SPD's coalition partner-and from the left wing of his own party threatened his leadership; third, he had reason to feel that he had been weakened politically, in and out of Parliament, by the devastating results of recent Land elections; fourth, and relatedly, he was faced with a CDU-dominated Bundesrat that could thwart 60 percent of his legislative program; finally, opinion polls show that the SPD-led government was at one of its lowest ebbs in popular support. Taken together, these factors added up to a strong argument for resorting to Article 68.

But were these reasons constitutionally sufficient to proceed with new elections? The legal objections were substantial. For one thing, as former Constitutional Court Justice Dieter Grimm (2005) suggested, Schröder was not "weary of office" (amtsmüde). He might have resigned but told the world that he would not do so. For another, he may not have been faced with a real parliamentary crisis. In short, a "situation of instability" may not have existed because, arguably, he still commanded a majority in the Bundestag. According to prevailing constitutional opinion, it is not the margin of a chancellor's parliamentary majority that is crucial but rather its stability (von Münch and Kunig 2001, 1172-75), and Schröder had not in fact lost his majority. In addition, the public's low opinion of a duly elected government has no constitutional relevance. Equally irrelevant is the nature of the relationship between the Bundestag and the Bundesrat. The relationship that counts is that between the Bundestag and the federal government. Article 68 may be invoked only when this relationship reaches the point of instability. The betting in this instance, however, was that the court would follow its 1983 precedent and validate the president's decision to dissolve Parliament and hold new elections.

This is precisely what happened. On August 25, 2005, the FCC once again held that the requirements of Article 68 had been fulfilled (Dissolution Case II; see www.bverfg.de/entscheidungen/es20050825_2bve000405.html). The court reemphasized its view that the Basic Law provides for no general power to dissolve Parliament. The majority was emphatic in saying that the president may not grant a chancellor's request for dissolution merely because he would wish to expand his parliamentary majority. In assessing the validity of the request, the president must be persuaded that the chancellor in fact is faced with a situation of instability in parliament. But again, the court felt, as it did in 1983, that this was largely a political question requiring a measurable degree of deference to the three political organs, namely, chancellor, Bundestag, and president. The deference was anything but total, however. Citing serious conflicts within the governing coalition-with some members of Schröder's own party calling for his resignation—and the chancellor's 
sincere doubts that he could govern effectively under these circumstances, not to mention the president's own careful evaluation of the chancellor's position, the court concluded that the president had not abused his discretion in approving Parliament's dissolution and calling for new elections. ${ }^{8}$ Dissolution II, with its interplay between law and politics, was as fascinating a spectacle for Germans as was Bush v. Gore for Americans.

\section{Concluding Remarks}

As this article has shown, the FCC is an important custodian of political democracy in Germany. It has protected the rights of parliamentarians and promoted equality of opportunity among competing political parties while guarding the integrity of elections and insisting on relatively equal population in single-member constituencies. It has also defended the principle of fair and equal representation exemplified in the nation's celebrated system of personalized or modified PR. And while the court has limited the right of foreign residents to vote in local and municipal elections, it has otherwise sought to root Parliament's law-making powers in elections and the exercise of the franchise. In addition, the FCC has vigilantly shielded minor parties against discriminatory legislation, particularly with respect to the allocation of state subsidies and requirements for gaining access to the ballot. At the same time, with the single exception of the first all-German election in 1990, the FCC has sustained the 5 percent rule at state and national levels in the interest of overall political stability. Finally, by exercising its authority to pass sentence on the validity of elections and the dissolution of parliament, the court has consolidated its reputation in Germany as the ultimate guardian of both democracy and the rule of law.

\section{Notes}

1. The sole exception are the referenda required when adjoining states (Länder) seek to change their boundaries or merge into a single state (Land). Article 29 of the Basic Law requires a referendum in the affected territories and the approval of two-thirds of those voting. Any general reorganization of the states must be approved in a national referendum.

2. The parenthetical reference contains the standard citation to German constitutional case law. The Federal Constitutional Court's (FCC's) decisions appear in a set of official reports known as Entscheidungen des Bundesverfassungsgerichts (Decisions of the Federal Constitutional Court) and are published by J.C.B. Mohr (Paul Siebeck), Tübingen, Germany. The citation format includes, in the sequence noted, the volume number, abbreviation of the court (BVerfGE), first page of the decision, the page of the particular reference (sometimes omitted), and the year of the case.

3. Germany was one of the first countries to establish a constitutional court after World War II. The following years witnessed an explosion of constitutional (or judicial) review around the world. The singularity of this phenomenon cannot be exaggerated. It is arguably the major political development of our time, and no less revolutionary. Consider: popular democracies have transformed themselves into juridical democracies, judicial has replaced parliamentary supremacy, elected representatives have relinquished power to unelected judges, and countermajoritarian institutions have been empowered to veto majoritarian policies. In short, what was once a unique aspect of American constitutionalism has evolved into a universal feature of 
the rule of law around the world. In contrast to the American experience, however, judicial review has been most often lodged, as in Germany, in a specialized constitutional court organized apart from and independent of the regular judiciary.

4. These panels are known as the First and Second Senates. The Bundestag elects one-half of the justices of each senate, the Bundesrat (the upper house of Parliament in which the Länder [states] are represented) the other half. The twelve-year limited term of office applies only to the justices of the Constitutional Court. They are required to retire, however, at the age of sixty-eight whether or not they have served the full term. All other German judges must retire when they reach sixty-five years of age.

5. The special arrangement for this first all-German election represented a compromise between West Germany's electoral system and East Germany's system of pure proportional representation. East German leaders objected to the 5 percent clause because the political reform groups that had played so critical a role in the nation's peaceful revolution would be unlikely to win 5 percent of the national vote. The two sides eventually worked out a "piggyback" arrangement that would permit smaller parties in the east to field candidates in alliance with other, larger parties in the west. This plan, however, favored some small parties at the expense of others. For example, the strength of Bavaria’s Christian Social Union (CSU) would carry its sister party, East Germany's German Social Union (GSU), into the Bundestag, whereas the old Communist Party, now dressed up as the Party of Democratic Socialism (PDS), was unlikely to find a willing partner in the west to help it win 5 percent of the national vote. The PDS, along with the Greens and far-right Republicans, petitioned the FCC to strike down the arrangement.

6. This concept of democratic legitimacy has also played a crucial role in cases implicating separation of powers. An example is the FCC's treatment of the nondelegation doctrine. Taking seriously the Basic Law's command that statutes define the "content, purpose, and scope" of delegated authority, the court has struck down numerous grants of authority to administrative officials. The U.S. Supreme Court, by contrast, would not touch cases such as these. In still another case, which the Supreme Court would have regarded as nonjusticiable, the court declared that parliamentary approval would be required for the further deployment of German troops in Somalia (89 BVerfGE 38: 1993).

7. An Organstreit proceeding is usually initiated by one organ—or branch—of government against another. A constituent unit or member of an organ of government, however, has standing before the FCC if his or her rights as an agent of the political organ have been violated. In this case, members of the Bundestag - the relevant political organ —were able to argue that the premature dissolution of Parliament infringed on their constitutional right to a four-year term of office.

8. Dissolution II included two dissenting opinions. Justice Gertrude Lübbe-Wolff wanted to dispense with the court's "material conditions" requirement, whereas Justice Hans-Joachim Jentch opined that the requirement was not satisfied. Both thought that the dissolution was fabricated in "clear violation" of the will of the Basic Law's framers.

\section{References}

Bundesverfassungsgericht. 2004. Statistical overview of proceedings. http://www.bverfg.de/cgi-bin/link .pl?entscheidungen (accessed July 7, 2005).

Chemerinsky, E. 2001. Bush v. Gore was not justiciable. Notre Dame Law Review 76:1093-1112.

Conradt, D. P. 2001. The German polity. 7th ed. New York: Longman.

Currie, D. 1994. The constitution of the Federal Republic of Germany. Chicago: University of Chicago Press.

Foster, N. G. 1994. The German constitution and E.C. membership. Public Law, pp. 392-408.

Franck, T. M. 1992. Political questions, judicial answers. Princeton, NJ: Princeton University Press.

Gillman, H. 2001. The votes that counted: How the Court decided the 2000 presidential election. Chicago: University of Chicago Press.

Grimm, D. 2005. Schröder's Weg ist ungangbar. Frankfurter Allgemeine Zeitung, June 8, p. 39.

Gunlicks, A. 1994. The New German party finance law. German Politics 4:101-21.

2003. The Länder and German federalism. Manchester, UK: Manchester University Press.

Jesse, E. 1985. Wahlrecht zwischen Kontinuität und Reform. Düsseldorf, Germany: Droste.

Kitzinger, U. W. 1960. German electoral politics. Oxford: Clarendon. 
Kokott, J. 1994. Deutschland im Rahmen der Europäischen Union—zum Vertrag von Maastricht. Archiv des Öffenlichen Rechts 119:207-37.

. 1999. From reception and transplantation to convergence of constitutional models in the age of globalization-With special reference to the German Basic Law. In Constitutionalism, universalism and democracy - A comparative analysis, ed. Christian Starck, 71-134. Baden-Baden, Germany: Nomos.

Kommers, D. 1976. Judicial politics in Germany: A study of the Federal Constitutional Court. Beverly Hills, CA: Sage.

. 1997. The constitutional jurisprudence of the Federal Republic of Germany. 2nd ed. Durham, NC: Duke University Press.

Leibholz, G. 1973. Der moderne Parteienstaat. In Verfassungsstaat_Verfassungsrecht. Stuttgart, Germany: Kohlhammer.

Meeson, K. M. 1994. Hedging European integration: The Maastricht judgment of the Federal Constitutional Court. Fordham International Law Journal 17:511-30.

Miller, R. 2004. Lords of democracy: The judicialization of "pure politics" in the United States and Germany. Washington and Lee Law Review 61:587-662.

Nassmacher, K.-H. 2001. Political finance in West Central Europe. In Foundations of democracy, ed. KarlHeinz Nassmacher, 92-111. Baden-Baden, Germany: Nomos.

Pernice, I. 1993. Maastricht, Staat, und Demokratie. Verwaltung 26:449.

Richter, M. 1995. The Basic Law and the democratic party state: Constitutional theory and political practice. In Cornerstone of democracy: The West German Grundgesetz, 1949-89. Washington, DC: German Historical Institute.

Ripple, K. 1984. Constitutional litigation. Charlottesville, VA: The Michie Company.

Sartori, G. 1997. Comparative constitutional engineering. 2nd ed. New York: New York University Press. Schlaich, K., and S. Korioth. 2001. Das Bundesverfassungsgerichts. 5th ed. Munich, Germany: C.H. Beck. von Münch, I., and P. Kunig. 2001. Grundgesetz Kommentar. 5th ed. Munich, Germany: C.H. Beck. 